\title{
Cd concentration of durum wheat grain as influenced by soil salinity
}

\author{
Faruk ÖZKUTLU1, Şevket Metin KARA²
}

${ }^{1}$ Department of Soil Science and Plant Nutrition, Faculty of Agriculture, Ordu University, Ordu

${ }^{2}$ Department of Field Crops, Faculty of Agriculture, Ordu University, Ordu

Alınış tarihi: 13 Ağustos 2018, Kabul tarihi: 5 Kasım 2018

Sorumlu yazar: Faruk ÖZKUTLU, e-posta: farukozkutlu@hotmail.com; fozkutlu@odu.edu.tr

\begin{abstract}
Cadmium (Cd) accumulation in plant tissues has recently gained a worldwide-growing concern due to food safety and health care. Soil salinity is an important causal agent influencing Cd accumulation in cereal grains and durum wheat is known as the most sensitive to $\mathrm{Cd}$ toxicity among cereals. This research is aimed at evaluating influence of soil salinity on cadmium accumulation in durum wheat grain. Influence of $\mathrm{NaCl}$ doses (0, 200 and $1000 \mathrm{mg}$ $\mathrm{kg}^{-1}$ ) on $\mathrm{Cd}$ concentration in durum wheat grain (Triticum turgidum L. durum) grown in soils treated with $\mathrm{Cd}\left(0\right.$ and $\left.1.0 \mathrm{mg} \mathrm{kg}^{-1}\right)$ was established. Grain $\mathrm{Cd}$ concentration in control plants (without $\mathrm{Cd}$ and $\mathrm{NaCl}$ ) was $21 \mu \mathrm{g} \mathrm{kg}^{-1}$, while 200 and $1000 \mathrm{mg} \mathrm{kg}^{-1}$ $\mathrm{NaCl}$ doses resulted in 60 and $75 \mu \mathrm{g} \mathrm{kg-1} \mathrm{Cd} \mathrm{with}$ $300 \%$ and $400 \%$ increase, respectively. Grain Cd concentration in Cd-treated soil arose from $1325 \mu \mathrm{g}$ $\mathrm{kg}^{-1}$ in the control plants to 1778 and $2411 \mu \mathrm{g} \mathrm{kg}^{-1}$ in the plants exposed to 200 and $1000 \mathrm{mg} \mathrm{kg}^{-1} \mathrm{NaCl}$, respectively. The present study reveals that soil salinity increases $\mathrm{Cd}$ accumulation in grain even if soil Cd level is very low. Further, cadmium is transported to grain easily and soil salinity enhances such carriage in Cd-contaminated soils.
\end{abstract}

Key words: Cadmium, heavy metal, $\mathrm{NaCl}$ salinity, salt, Triticum turgidum L.

\section{Toprak tuzluluğu etkisindeki makarnalık buğday tanesinin kadmiyum konsantrasyonu}

\section{$\ddot{0} \mathbf{z}$}

Bitki dokularında kadmiyum (Cd) birikimi, gıda güvenliği ve insan sağlığı açısından, tüm dünyada gittikçe artan bir ilgi çekmektedir. Toprak tuzluluğu tahıl tanelerinde kadmiyum birikimine yol açan önemli bir faktördür. Makarnalık buğday tahıllar arasında Cd toksitesine en hassas olan bitki olarak bilinmektedir. $\mathrm{Bu}$ araștırma, toprak tuzluluğunun makarnalık buğday tanesinde kadmiyum birikimi üzerine etkisini belirlemek amacıyla yürütülmüştür. Kadmiyum uygulanan ve uygulanmayan ( 0 ve $1.0 \mathrm{mg}$ $\mathrm{kg}^{-1}$ ) topraklarda yetiștirilen makarnalık buğday (Triticum turgidum L. durum) tanesinin Cd içeriği üzerine $\mathrm{NaCl}$ dozlarının $\left(0,200\right.$ ve $\left.1000 \mathrm{mg} \mathrm{kg}^{-1}\right)$ etkisi incelenmiştir. Kontrol bitkilerde (kadmiyum ve $\mathrm{NaCl}$ uygulanmamış) tanenin Cd konsantrasyonu $21 \mu \mathrm{g} \mathrm{kg}^{-1}$ olarak tespit edilierken, 200 ve $1000 \mathrm{mg}$ $\mathrm{kg}^{-1} \mathrm{NaCl}$ dozlarında bu değerler, sirasıyla \%300 ve \%400 artışla, 60 ve $75 \mu \mathrm{g} \mathrm{kg}{ }^{-1}$ olmuştur. Kadmiyum uygulanmış toprakta tanenin $\mathrm{Cd}$ içeriği kontrol bitkilerinde $1325 \mu \mathrm{g} \mathrm{kg}^{-1}$ olurken, 200 ve $1000 \mathrm{mg}$ $\mathrm{kg}^{-1} \mathrm{NaCl}$ ile muamele edilen bitkilerde 1778 ve 2411 $\mu \mathrm{g} \mathrm{kg}^{-1}$ olmuştur. Sunulan bu çalışma, topraktaki Cd seviyesi çok düşük olsa bile, toprak tuzluluğunun tanede Cd birikimini artırdığını ortaya koymaktadır. Ayrıca, kadmiyum kolayca taneye taşınmaktadır ve Cd ile bulaşık topraklarda toprak tuzluluğu bu taşınımı atırmaktadır.

Anahtar kelimeler: Ağır metal, kadmiyum, NaCL tuzluluğu, Triticum turgidum L., tuz

\section{Introduction}

Grain cereals such as wheat, maize and rice supply the main foods required throughout the world. With a total production of almost 650 million tons a year, wheat is considered as being the constant food for more than half of the world's population (Fao, 2012). As in many other plants, worldwide interest on piling up heavy metals such as cadmium (Cd) in wheat grain has recently increased due to food safety issues. Wheat genotypes, particularly in durum wheat, show a great variation in accumulation of cadmium in their grains. Genotypes of durum wheat tend to pile up more $\mathrm{Cd}$ in their 
grains than those of bread wheat (Mglaughlin et al, 1998). Cadmium basically enters in crop plants through roots from soil (Black et al, 2014). Cadmium convenience in soils is determined by numerous factors including organic material, cation exchange capacity (CEC), soil Cd content, soil $\mathrm{pH}$, and soil salinity (Ozkutlu et al, 2007; He et al, 2015; Ran et al, 2016). Considering various soil factors, soil salinity is supposed to be the most important one affecting $\mathrm{Cd}$ accumulation in plant tissues (Mclaughlin et al, 1997; Li et al 2014; Liu et al 2014). Salinity affects at least $20 \%$ of world's arable lands (Rhoades, 1990). It has been reported that, chloride-derived soil salinity increases the mobility of $\mathrm{Cd}$ in soil (Lopez-Chuken, 2005; Weggler-Beaton 2000). Under relatively high $\mathrm{Cl}^{-}$concentrations and soil salinity conditions, as it occurs in some saline soils, the solubility and mobility of Cd may be increased substantially. It is indicated that cadmium levels in soil solution and also shoots of wheat and Swiss chard plants enhanced as $\mathrm{Cl}^{-}$concentration in biosolids-amended soil increased. It has been well documented that cadmium can be easily transported from soil to crop plants. Cd-contaminated food through the food chain is the basic source of Cd entry to human body (Dai et al, 2012). Cadmium contamination of agricultural soils and edible foods threaten biodiversity, food safety and human health. In many countries, federal agencies have established critical limits on the concentration of $\mathrm{Cd}$ in foods. The FAO/World Health Organization (Fao, 2012) has set a concentration limit of $0.1 \mathrm{mg} \mathrm{Cd} \mathrm{kg}^{-1}$ in grain of wheat for human consumption. In the light of these findings, the purpose of this research is to investigate influence of $\mathrm{NaCl}$ on accumulation of cadmium in grain of durum wheat.

\section{Material Methods}

\section{Glasshouse experiment}

Durum wheat (Triticum turgidum L.) variety Balcalı2000 was used as the test crop in the experiment. In the study, a severely Zn-deficient soil from Central Anatolia of Turkey was used, whit a very low $\mathrm{Zn}$ availability (Cakmak, 1996) (DTPA 0.08 mg Zn kg-1 soil). The analysis of all chemical and physical properties of the soils were carried out using standard methods (Schliching E, 1996; Lindsay 1978). The soil total $\mathrm{Cd}$ concentration was $0.27 \mathrm{mg}$ $\mathrm{kg}^{-1}$ and DTPA-extractable Cd was $0.005 \mathrm{mg} \mathrm{kg}^{-1}$. Durum wheat seeds (Triticum turgidum L. durum, cv. Balcali-2000) were sown in plastic pots including 2,7 $\mathrm{kg}$ soil and grown in a greenhouse. The soil used in the study had a clay texture with a pH of 8.1 , soil salinity of EC $23 \mu \mathrm{Sm}^{-1}$ and contained $0.7 \%$ organic matter and $14 \% \mathrm{CaCO}_{3}$, measured by the method explained by Jackson (Jackson, 1958). About 10 seeds in experiment were planted in each pot, and the seedlings were thinned to 5 seedlings per pot after emergence. A basic fertilizer of $400 \mathrm{mg} \mathrm{N} \mathrm{kg}^{-1}$ soil as $\mathrm{Ca}\left(\mathrm{NO}_{3}\right)_{2}, 150 \mathrm{mg} \mathrm{P} \mathrm{kg}{ }^{-1}$ soil as $\mathrm{KH}_{2} \mathrm{PO}_{4}, 2.5 \mathrm{mg}$ Fe kg-1 soil as Fe-EDTA and $1.0 \mathrm{mg} \mathrm{Zn} \mathrm{kg}^{-1}$ soil as $\mathrm{ZnSO}_{4}$ was applied to all pots. The dose of $\mathrm{Cd}$ used was $1 \mathrm{mg} \mathrm{Cd} \mathrm{kg}^{-1}$ in the form of $\mathrm{CdSO}_{4}$ prior to sowing. The pots were brought to field capacity moisture and then irrigated regularly with deionized water. The wheat plants were grown in a glasshouse having an evaporative cooling system. Wheat plants, grown until grain maturity, were harvested after 163 days of growth and the spikes were collected and the grains were subjected to monitor $\mathrm{Cd}$ and $\mathrm{Zn}$. The concentrations of all metals were measured by inductively coupled argon plasma optical emission spectrometry (Jobin-Yvon, JY138-Ultrace) after digesting the seeds in $65 \%(\mathrm{w} / \mathrm{w})$ nitric acid with a closed microwave system (Milestone, 1200-Mega). An inductively coupled argon plasma-optical emission spectrometer (ICP with; U-5000AT+ Ultrasonic Nebulizer; Cetac Technologies, Omaha, NE, USA) (214.438 $\mathrm{nm} / 0.1 \mu \mathrm{g} \mathrm{kg}{ }^{-1}$ ) was used to determine cadmium concentration in the extracts of grain. Corn bran (Standard Reference Material, 8433) of certified reference material was used to check analytical recovery of the method.

\section{Results and Discussion}

A greenhouse experiment has been conducted to evaluate the influence of $\mathrm{NaCl}$ on $\mathrm{Cd}$ and $\mathrm{Zn}$ concentration of durum wheat grain. Balcalı 2000 durum wheat (Triticum durum L.) cultivar has been grown in increasing $\mathrm{NaCl}$ doses with and without cadmium application. The evident difference was found between $\mathrm{Cd}$ treatment and the control for grain dry matter. As expected, increasing $\mathrm{NaCl}$ applications decreased the grain yield (Table 1). In comparison with the control, $\mathrm{NaCl}$ or $\mathrm{Cd}$ alone and the combination of $\mathrm{NaCl}$ and $\mathrm{Cd}$ treatments led to significant decline in the grain dry matter. In control application, grain dry weight was found as $6.6 \mathrm{~g}$ plant $\mathrm{t}^{-1}$ but in $1.0 \mathrm{~g} \mathrm{NaCl} \mathrm{kg}^{-1}$ application it decreased to $3,6 \mathrm{~g} \mathrm{plant}^{-1}$ with a $45 \%$ reduction. A few researchers have explained that soil salinity has increased $\mathrm{Cd}$ concentration in crops which are grow on soils fertilized with phosphorus fertilizers containing its salts (Mclaughlin et al., 1994; 
Smolderds et al, 1997; Helal et al, 1999). Therefore, $\mathrm{Cd}$ and salinity interaction effect should be taken into account in places where these stresses are expected to limit crop growth and yield.

Table 1. Grain dry weight (g plant ${ }^{-1}$, mean \pm std.) of durum wheat grown under increased $\mathrm{NaCl}$ and Cd application

\begin{tabular}{ccc}
\hline \multirow{2}{*}{$\mathrm{NaCl}$ applications } & \multicolumn{2}{c}{ Cd applications } \\
\cline { 2 - 3 } & $0 \mathrm{mg} \mathrm{Cd} \mathrm{kg}-1$ & $1.0 \mathrm{mg} \mathrm{Cd} \mathrm{kg}^{-1}$ \\
\hline Control & $6.6 \pm 0.3$ & $5.1 \pm 0.2$ \\
$0.2 \mathrm{~g} \mathrm{NaCl} \mathrm{kg}^{-1}$ & $5.7 \pm 0.2$ & $5.2 \pm 0.9$ \\
$1.0 \mathrm{~g} \mathrm{NaCl} \mathrm{kg}^{-1}$ & $3.6 \pm 0.2$ & $3.7 \pm 0.1$ \\
\hline
\end{tabular}

Table 2. Grain Cd concentration ( $\mu \mathrm{g} \mathrm{kg}^{-1}$, mean \pm std.) of durum wheat grown under increased $\mathrm{NaCl}$ and $\mathrm{Cd}$ application

\begin{tabular}{ccc}
\hline \multirow{2}{*}{$\mathrm{NaCl}$ applications } & \multicolumn{2}{c}{ Cd applications } \\
\cline { 2 - 3 } & $0 \mathrm{mg} \mathrm{Cd} \mathrm{kg}^{-1}$ & $1.0 \mathrm{mg} \mathrm{Cd} \mathrm{kg}^{-1}$ \\
\hline Control & $21 \pm 8.6$ & $1325 \pm 365$ \\
$0.2 \mathrm{~g} \mathrm{NaCl} \mathrm{kg}^{-1}$ & $60 \pm 7.6$ & $1778 \pm 317$ \\
$1.0 \mathrm{~g} \mathrm{NaCl} \mathrm{kg}^{-1}$ & $75 \pm 5.7$ & $2411 \pm 109$ \\
\hline
\end{tabular}

Cadmium concentration in grain increased significantly when plants were subjected to $\mathrm{Cd}$ containing medium, compared to the control. The $\mathrm{NaCl}$ salinity produced a significant change in $\mathrm{Cd}$ concentration of durum wheat grain, and grain $\mathrm{Cd}$ concentration increased with increasing $\mathrm{Cd}$ and $\mathrm{NaCl}$ levels. In control pot (without $\mathrm{NaCl}$ and $\mathrm{Cd}$ ), grain $\mathrm{Cd}$ concentration was $21 \mu \mathrm{g} \mathrm{kg}^{-1}$ but in application $0.2 \mathrm{~g}$ $\mathrm{NaCl} \mathrm{kg-1}$ and 1,0 $\mathrm{g} \mathrm{NaCl} \mathrm{kg}^{-1}$ it increased about three fold and four fold, respectively (Table 2). Salinity inhibits photosynthesis $(\mathrm{Qu}, 2012)$ and is a growth reduction factor causing a strong decrease in the yield of cultivated plants. The amount of $\mathrm{Cd}$ in soil solution can be enhanced significantly by chloride salinity (Smolders and Mclaughlin, 1996; Pandolfi et al, 2012), mainly by increased solubility of Cd via the formation of chloro-complexes of Cd (Lopez and Young, 2005). In this study, the effect of the combined stress $(\mathrm{NaCl}+\mathrm{Cd})$ on grain $\mathrm{Cd}$ concentration was basically similar to that of $\mathrm{NaCl}$ alone. Furthermore, more increase occurred in $\mathrm{NaCl}$ $+\mathrm{Cd}$ stress than Cd stress alone. In application of 1.0 mg Cd kg-1 to soil (without $\mathrm{NaCl}$ ), Cd concentration in grain was determined as $1325 \mu \mathrm{g} \mathrm{kg}^{-1}$. In combined application $(\mathrm{NaCl}+\mathrm{Cd})$, Cd concentration in grain increased from 1325 to $2411 \mu \mathrm{g} \mathrm{kg}^{-1}$ (Table 2). This result shows a good agreement with the result of (Rhoades and Loveday, 1990; Mclaughlin et al 1994; Li et al 1994; Lopez and Young, 2010), who reported that grain $\mathrm{Cd}$ concentration could be increased by $\mathrm{NaCl}$ application. A similar study revealed that $\mathrm{Cd}$ in the soil could be mobilized by chloride $\left(\mathrm{Cl}^{-}\right)$and its uptake by wheat increased, particularly by mobilizing inherent soil Cd (Dahlin et al, 2016). Another finding in our study, whit low $\mathrm{Cd}$ concentration in grain, $\mathrm{Zn}$ concentration was high. When Cd concentration of control plant determined as $1325 \mu \mathrm{g} \mathrm{kg}-1$, Zn concentration in grain was $23 \mathrm{mg}$ $\mathrm{kg}^{-1}$ (Table 3). Whereas, Cd concentration of grain was $2411 \mu \mathrm{g} \mathrm{kg}^{-1}$, while $\mathrm{Zn}$ concentration decreased to $16 \mathrm{mg} \mathrm{kg}^{-1}$ (Table 3). This finding is in agreement with Liu et al. stated that treatment of $\mathrm{Zn}$ reduced $\mathrm{Cd}$ concentration in durum wheat seedlings in comparison to Cd-stressed wheat (Liu et al, 2007).

Table 3. Grain Zn concentration ( $\mathrm{mg} \mathrm{kg}^{-1}$ ) of durum wheat grown under increased $\mathrm{NaCl}$ and $\mathrm{Cd}$ application

\begin{tabular}{ccc}
\hline \multirow{2}{*}{$\mathrm{NaCl}$ applications } & \multicolumn{2}{c}{ Cd applications } \\
\cline { 2 - 3 } & $0 \mathrm{mg} \mathrm{Cd} \mathrm{kg}^{-1}$ & $1.0 \mathrm{mg} \mathrm{Cd} \mathrm{kg}^{-1}$ \\
\hline Control & $20 \pm 1.7$ & $23 \pm 1.0$ \\
$0.2 \mathrm{~g} \mathrm{NaCl} \mathrm{kg}^{-1}$ & $19 \pm 0.7$ & $16 \pm 2.2$ \\
$1.0 \mathrm{~g} \mathrm{NaCl} \mathrm{kg}^{-1}$ & $17 \pm 1.4$ & $16 \pm 0.4$ \\
\hline
\end{tabular}

This situation can be explained with $\mathrm{Cd}$ and $\mathrm{Zn}$ interaction and various reports stated that $\mathrm{Zn}$ application has resulted in a decrease in $\mathrm{Cd}$ concentration of wheat grain (Liu et al, 2007; Zhao, 2011; Li, 2012; Singh, 2013). Many studies have revealed that in the presence of salinity $\left(\mathrm{NaCl}^{-}\right)$, the increase both in $\mathrm{Cd}$ uptake and accumulation is a general trend commonly occurring in several edible crops. Association between increased Cd content and chloride salinity in soils has been reported in some edible crops (Rhoades and Loveday, 1990; Lopez and Young, 2010) (alfalfa, maize and sunflower), potato tubers (Mclaughlin et al, 1997) and wheat grain (Norvell, 2000).

\section{Conclusion}

The findings of this study revealed that grain $\mathrm{Cd}$ concentration increased with increasing applied $\mathrm{Cd}$ and $\mathrm{NaCl}$ levels. In addition, soil salinity resulted in an increase in $\mathrm{Cd}$ accumulation in durum wheat grain even in low soil Cd level. Furthermore, in Cdcontaminated soils, this transportation of $\mathrm{Cd}$ is enhanced by soil salinity. Therefore, it is necessary to determine concentrations of $\mathrm{Cd}$ and other heavy metals of agricultural soils before the end of the growing season in areas with saline soils.

\section{References}

Black, A., Mclaren, R., Speir, T.W., Clucas, L., Condron, L.M. 2014. Gradientdif-ferences in soil metal solubility and uptake by shoots and roots of wheat. Biology and Fertility of Soils, 50: 685-694. 
Cakmak, I., Sari, N., Marschner, H., Ekiz, H., Kalayci, M., Yilmaz, A., 1996. Phytosiderophore release in bread and durum wheat genotypes differing in zinc efficiency. Plant and Soil, 180: 183-189.

Dahlin, A.S., Eriksson, J., Campbell, C.D., Oborn, I. 2016. Soil amendment affects Cd uptake by wheat are we underestimating the risks from chloride inputs? Science of the Total Environment, 554: 349-357.

Dai, X.P., Feng, L., Ma, X.W., Zhang, Y.M. 2012. Concentration level of heavy metals in wheat grains and the health risk assessment to local inhabitants from Baiyin, Gansu, Journal of the Chinese Advanced Materials Society, 518: 951-956.

FAO, 2012. http://faostat.fao.org.

He S., He, Z., Yang X., Stoffella P.J., Baligar V.C. 2015. Soil biogeochemistry, plant physiology. Advances in Agronomy. 06.005.

Helal, H.M., Upenov, A., Issa, G. 1999. Growth and uptake of $\mathrm{Cd}$ and $\mathrm{Zn}$ by Leucaena leucocephala in reclaimed soils as affected by $\mathrm{NaCl}$ salinity. Journal of Plant Nutrition and Soil Science, 162: 589-592.

Jackson, M.L. 1958. Soil chemical analysis. Prentice-Hall, Inc.; Englewood Cliffs.

Li, D.D., Zhou, D.M. 2012. Acclimation of wheat to low-level cadmium or zinc resistance to cadmium toxicity. Ecotoxicology Safety, 79: 264-271.

Li, Y., Wang, L., Yang, L., Li, H. 2014. Dynamics of rhizosphere properties and antioxidative responses in wheat under cadmium stress. Ecotoxicology and Environmental Safe, 102: 55-61.

Li, Y.M., Chaney, R.L., Schneiter, A.A. 1194. Effect of soil chloride on cadmium concentration in sunflower kernels. Plant Soil, 167: 275-280.

Lindsay, W.L., Norvell, W.A. 1978. Development of a DTPA soil test for zinc, iron, manganese and copper. Soil Science Society of America Journal, 42(3): 421-428.

Liu, K,, L.V, J., He, W., Zhang, H., Cao , Y., Dai, Y. 2015. Major factors influencing cadmium uptake from the soil into wheat plants. Ecotoxicology and Environmental Safety, 113: 207-213.

Liu, Q., Tjoa, A., Römheld, V. 2007. Effects of chloride and co-contaminated zinc on cadmium accumulation. Bullof Environment Cont and Toxicol, 79 (1):62-65.

López-Chuken, U.J., Young, S.D. 2005. Plant screening of halophyte species for cadmium phytoremediation. Zeitschrift für Naturforschung, 60: 236-243.

López-Chuken, U.J., Young, S.D. 2010. Modelling sulphateenhanced cadmium uptake by $Z$. mays from nutrient solution. J Environment Sci, 22(7): 80-85.

Mclaughlin, M.J, Williams, C.M.J., Mckay, A., Kirkham, R., 1994. Effect of cultivar on uptake of cadmium by potato tubers. Australian Journal of Agricultural Research, 45: 1483-1495.

Mclaughlin, M.J., Andrew, S.J., Smart, M.K., Smolders, E. 1998. Effects of sulfate on cadmium uptake by Swiss chard:. Plant and Soil, 202: 211-216.

Mclaughlin, M.J., Tiller, K.G., Smart, M.K. 1997. Speciation of cadmium in soils solution of saline/sodic soils and relationship with cadmium concentrations. Australian Journal of Soil Research, 35: 1-17.

Norvell, W.A., Wu, J., Hopkins, D.G., Welch, R.M. 2000. Association of cadmium in durum wheat grain with soil chloride and chelate. Soil Science Society of America Journal, 64(6): 2162-2168.

Ozkutlu, F., Ozturk, L., Erdem, H., Mclaughlin, M., Cakmak, I. 2007. Leaf-applied sodium chloride promotes cadmium accumulate. Plant and Soil, 290: 323-331.

Pandolfi, C., Mancuso, S., Shabala, S. 2012. Physiology of acclimation to salinity stress in pea. Environmental and Experimental Botany, 84: 44-51.

Qu, C., Liu, C., Gong, X., Li, C., Hong, M., Wang, L., 2012. Impairment of maize seedling photosynthesis caused by a combination of potassium deficiency. Environ and Experimental Botany, 75: 134-141.

Ran, J., Wang, D., Wang, C., Zhang, G., Zhang, H. 2016. Heavy metal contents, distribution, and prediction in a regional soil-wheat system. Science of the Total Environment, 544: 422-431.

Rhoades, J.D., Loveday, J. 1990. Salinity in irrigated agriculture. Agronomy, 30, 1089-1142.

Schlichling, E., Blume, H.P. 1996. Bodenkundliches Praktikum, Verlang Paul Parey, Hamburg-Berlin.

Singh, A., Shivay., Y.S. 2013. Residual effect of summer green manure crops and $\mathrm{Zn}$ fertilization on quality and $\mathrm{Zn}$ concentration of durum wheat Biological Agriculture and Horticulture, 29: 271-287.

Smolders, E., Lambrechts, R.M., Mclaughlin, M.J., Tiller, K.G. 1997. Effect of soil solution chloride on $\mathrm{Cd}$ availability to Swiss chard. Journal of Environmental Quality, 27(2): 426-431.

Smolders, E., Mclaughlin M.J. 1996. Chloride increases cadmium uptake in Swiss chard in a resin-buffered nutrient solution. Soil Science Society of America Journal, 60 (5): 1443-1444.

Weggler-Beaton, K., Mclaughlin, M.J., Graham, R.D. 2000. Salinity increases cadmium uptake by wheat and Swiss chard drom soil amended with biosolids. Australian Journal of Soil Research, 38 (1): 37-46.

Zhao, A.Q., Tian, X.H., Lu, W.H., Gale, W.J., Lu, X.C., Cao, Y.X. 2011. Effect of zinc on cadmium toxicity in winter wheat. Journal of Plant Nutrition, 34: 1372-1385. 